\title{
Efektivitas Model Pembelajaran Think Talk Write Terhadap Kemampuan Menulis Matematik Ditinjau Dari Disposisi Matematik Siswa SMP
}

\author{
(The Effectiveness of Think Talk Write Learning Model on the Mathematic Writing Ability \\ Viewed from Mathematic Disposition of Junior High School Students)
}

\author{
Darmawangsa $^{1}$, Kodirun ${ }^{2}$, Hafiludin Samparadja ${ }^{2}$ \\ ${ }^{1}$ Guru SMP Negeri 25 Konawe Selatan, Alumnus Prodi Pendidikan Matematika PPs Universitas Halu Oleo \\ ${ }^{2}$ Dosen Pendidikan Matematika FKIP dan PPS Universitas Halu Oleo; Co-author: \\ kodirun_zuhry@yahoo.co.id
}

\begin{abstract}
Abstrak: Tujuan dari penelitian ini adalah untuk mengetahui perbedaan KMM siswa yang mengikuti model pembelajaran TTW dan siswa yang mengikuti model pembelajaran langsung ditinjau dari Disposisi Matematik (DM) siswa. Populasi dalam penelitian ini adalah seluruh siwa kelas VIII SMP Negeri 25 Konawe Selatan yang terdiri dari 3 kelas pararel. Pengambilan sampel dalam penelitian ini menggunakan teknik purposive sampling dan random class. Teknik pengumpulan data dilakukan dengan pemberian tes KMM siswa berbentuk tes uraian, angket DM dan lembar observasi. Data dianalisi dengan menggunakan statistik deskriptif dan statistik inferensial dengan uji hipotesis menggunakan Uji $\mathrm{t}$ beda dua rata-rata dari data $\mathrm{N}$-Gain kemampuan berpikir kritis matematis siswa. Hasil penelitian menunjukkan bahwa: (1) Terdapat peningkatan KMM siswa setelah diajar dengan model pembelajaran TTW; (2) Terdapat peningkatan KMM siswa setelah diajar dengan model pembelajaran langsung; (3) Secara signifikan rata-rata peningkatan KMM siswa yang diajar dengan model pembelajaran TTW lebih tinggi daripada rata-rata peningkatan KMM siswa yang diajar dengan model pembelajaran langsung; (4) Secara signifikan KMM siswa yang diajar dengan model pembelajaran TTW lebih tinggi daripada KMM siswa yang diajar dengan model pembelajaran langsung, baik ditinjau dari siswa yang memiliki DM tinggi, DM sedang maupun DM rendah.
\end{abstract}

Kata kunci: Kemampuan Menulis Matematik, Disposisi Matematik, Model Pembelajaran Think Talk Write

\begin{abstract}
The purpose of this study was to find out the difference in the MWA demonstrated by students who learnt under the TTW model and that shown by their cohorts who learnt via a direct method as viewed from their Mathematic Disposition (MD). Population of the study included all students of class VIII in SMP Negeri 25 of South Konawe, comprising of 3 parallel classes. Samples were determined using the purposive sampling technique and random class. Techniques of data collection were a written test, designed to measure students' MWA, and a questionnaire. Data were analyzed using a descriptive atatistics and inferential statistics, while hypotheses were tested using the t-test of two different mean score obtained from N-gain of the students' mathematics writing ability. Results showed that: (1) there was an improvement in the MWA of the students who learnt under the TTW model; (2) there was an improvementin the MWA of the students who learnt under the direct model; (3) the average of MWA score gained by the students in the TTW class was significantly higher than that gained by their cohorts in the direct class; (4) the average of MWA score gained by the students in the TTW class was significantly higher than that gained by their cohorts in the direct class, as viewed either from hight MD, medium MD, or low MD.
\end{abstract}

Keywords: Mathematics writing ability, Mathematics Disposition, Think Talk Write Learning Model.

\section{PENDAHULUAN}

Matematika merupakan salah satu mata pelajaran yang harus diajarkan di sekolah, karena matematika membekali siswa untuk berpikir logis, analitis,

sistematis, kritis dan kreatif. Peningkatan kualitas pembelajaran merupakan salah satu pilar penting untuk peningkatan mutu pendidikan secara keseluruhan. 
Pembelajaran yang berkualitas dan efektif sangat diperlukan oleh siswa dan guru. Model pembelajaran yang berkualitas dapat diterapkan dengan tidak menjadikan guru sebagai satu-satunya sumber ilmu yang tidak boleh dibantah, tetapi guru dan siswa merupakan dua bagian penting dalam tercapainya proses pembelajaran yang saling melengkapi.

Para ahli pendidikan dan para perancang kurikulum merumuskan empat kemampuan matematika yang diharapkan dapat dicapai siswa mulai dari tingkat dasar sampai tingkat menengah. Keempat kemampuan matematika tersebut adalah penalaran, pemecahan masalah, koneksi dan komunikasi. Hal ini sesuai dengan pernyataan Adams dan Hamm (2010:102) tentang peran matematika yang digolongkan menjadi empat macam, yaitu: (1) matematika sebagai suatu cara untuk berpikir; (2) matematika sebagai suatu alat; (3) matematika sebagai suatu pemahaman tentang pola dan hubungan; (4) matematika sebagai bahasa atau alat untuk berkomunikasi.

Pentingnya mengaitkan pengalaman kehidupan nyata anak dengan ide-ide matematika dalam pembelajaran di kelas disampaikan oleh (Soedjadi 2000:30). Menurut Freudenthal (1991:102), bila anak belajar matematika terpisah dari pengalaman mereka sehari-hari maka anak akan cepat lupa dan tidak dapat mengaplikasikan metematika. Disamping itu, dengan berkembangnya Ilmu Pengetahuan, Teknologi dan Sains (IPTEKS) yang sangat pesat terutama dalam bidang telekomunikasi dan informasi maka siswa dituntut untuk mampu mengikuti perkembangan tersebut. Sebagai akibat dari kemajuan teknologi komunikasi dan informasi tersebut, arus informasi datang dari berbagai penjuru dunia secara cepat dan melimpah ruah.

Masih rendahnya kemampuan koneksi matematis siswa berdampak pada rendahnya prestasi belajar. Hal ini sesuai dengan temuan Wahyudin (1999: 191-
192) dalam penelitiannya yang menemukan bahwa salah satu kecenderungan yang menyebabkan sejumlah siswa gagal menguasai dengan baik pokok-pokok bahasan dalam matematika akibat siswa kurang menggunakan nalar dan logis dalam menyelesaikan soal atau persoalan matematika yang diberikan. Masih rendahnya kemampuan koneksi matematis siswa, tidak lepas dari kegiatan pembelajaran yang dilakukan guru di kelas. Hal ini sejalan dengan hasil observasi yang dilakukan oleh peneliti di SMPN 25 Konawe Selatan. Proses pembelajaran matematika yang biasa dilakukan kurang memberikan kesempatan kepada siswa untuk menggali dan menemukan sendiri konsep-konsep matematika, serta guru jarang menjelaskan serta memberikan contoh soal maupun latihan-latihan soal yang berkaitan soal yang mengoneksikan suatu masalah ke dalam situasi lain dalam pembelajaran matematika sehingga kemampuan koneksi matematikanya masih sangat rendah.

Salah satu model pembelajaran yang relevan untuk meningkatkan kemampuan menulis matematik siswa adalah Model Pembelajaran Think Talk Write (TTW). Teori TTW sejalan dengan teori belajar yang berkembang saat ini, seperti konstruktivisme dan pembelajaran kontekstual (Contextual Teaching and Learning, disingkat CTL). Namun, baik pendekatan konstruktivis maupun CTL mewakili teori belajar secara umum, TTW adalah suatu model pembelajaran yang dikembangkan khusus untuk matematika. yaitu suatu pembelajaran yang menghadapkan siswa pada situasi masalah kehidupan nyata (autentik) dan bermakna, memfasilitasi siswa untuk memecahkannya melalui penyelidikan/inkuiri dan kerjasama, memfasilitasi dialog dari berbagai segi, mendorong siswa untuk menghasilkan karya pemecahan dan peragaan hasil. 
Dari uraian tersebut, peneliti merasa perlu meneliti tentang Efektivitas Model Pembelajaran Think Talk Write (TTW) Terhadap Kemampuan Menulis Matematik

\section{METODE PENELITIAN}

Jenis penelitian ini merupakan penelitian Quasi Experiment dengan pretest-posttest control group design. Unsur dari penelitian ini ditentukan berdasarkan kategori DM siswa, Model pembelajaran TTW dan model pembelajaran langsung. Dengan demikian, untuk mengetahui efektivitas model pembelajaran TTW dan DM terhadap kemampuan menulis matematik siswa dilakukan dengan desain Pretest-Posttest Control Group Design.

Jenis data dalam penelitian ini merupakan data kuantitatif yang diperoleh dari hasil tes kemampuan menulis matematik serta data kualitatif yang diperoleh dari angket DM siswa. Pada penelitian ini pengumpulan data dilakukan melalui tes dan non tes. Tes diberikan

\section{HASIL PENELITIAN}

Pada analisis deskriptif dikemukakan gambaran disposisi matematik siswa dan kemampuan menulis matematik siswa yang diteliti, serta bagaimana aktivitas siswa dalam kelas dengan menggunakan kedua model pembelajaran tersebut. Sedangkan pada analisis inferensial dikemukakan hasilhasil pengujian hipotesis untuk mengungkap perbedaan pengaruh penerapan model pembelajaran TTW dan model pembelajaran langsung terhadap kemampuan menulis matematik siswa berdasarkan kategori disposisi matematik.

Uji statistik yang digunakan untuk menjawab hipotesis tersebut adalah Anava dan uji-t beda dua rata-rata. Sebelum melakukan uji statistik, terlebih dahulu dilakukan uji asumsi, yaitu uji normalitas data dengan menggunakan uji Kolmogorov-Smirnov dan uji homogenitas varians dengan menggunakan uji Levene. ditinjau dari Disposisi Matematik (DM) Siswa SMP.

untuk mengukur kemampuan Menulis matematik dan non tes yang diberikan berupa angket untuk mengukur tingkat disposisi matematik siswa.

Statistik deskriptif digunakan untuk mendeskripsikan nilai yang diperoleh masing-masing kelas dalam bentuk ratarata, nilai maksimum, nilai minimum dan standar deviasi. Analisis inferensial dalam penelitian ini digunakan untuk menguji hipotesis penelitian, namun terlebih dahulu melalui tahapan uji yang lain, yaitu uji normalitas dan uji homogenitas sebagai uji prasyarat untuk melakukan uji hipotesis. Data yang digunakan dalam uji normalitas dan uji-t berbentuk skor Normalized Gain (N-gain) dan uji t beda dua rata-rata

Hasil analisis validitas berdasarkan uji coba instrument disposisi matematik yang diberikan kepada 50 orang siswa diperoleh 40 butir peryataan yang valid dan 5 butir pernyataan yang tidak valid.

Pengkategorian DM dari kedua kelas menggunakan interval yang sama. Pada interval $\mathrm{X} \geq 118.05$ merupakan kategori DM tinggi yang diperoleh dengan rumus pengkategorian: $\mathrm{X} \geq$ mean $+0.5 \mathrm{SD}$, pada interval $\mathrm{X}<103.64$ merupakan kategori DM rendah yang diperoleh dengan rumus pengkategorian: $X<$ mean $-0.5 \mathrm{SD}$, dan DM sedang berada pada interval $103.64 \leq$ $\mathrm{X}<118.05$ yang diperoleh dengan menggunakan rumus pengkategorian: mean $-0.5 \mathrm{SD} \leq \mathrm{X}<$ mean $+0.5 \mathrm{SD}$. Mean dan SD yang digunakan adalah mean dan SD dari seluruh sampel dengan nilai mean $=110.84$ dan $\mathrm{SD}=14.41$.

Rangkuman hasil analisis deskriptif data DM siswa pada kelas yang diberi 
perlakuan berupa model pembelajaran

TTW disajikan pada Tabel berikut

Tabel 1. Deskriptif Data DM Siswa Pada Kelas yang diberi model pembelajaran

\begin{tabular}{cccc}
\multicolumn{4}{c}{ TTW } \\
\hline Kelas Interval & Kategori & Frek & $\mathbf{( \% )}$ \\
\hline $\mathrm{X} \geq 118.05$ & Tinggi $(\mathrm{T})$ & 9 & 37.50 \\
$103.64 \leq \mathrm{X}<118.05$ & Sedang $(\mathrm{S})$ & 7 & 29.17 \\
$\mathrm{X}<103.64$ & Rendah $(\mathrm{R})$ & 8 & 33.33 \\
Jumlah & & 24 & 100 \\
\hline
\end{tabular}

Rangkuman hasil analisis deskriptif data DM siswa yang mengikuti Tabel 2.

pembelajaran langsung disajikan pada

Tabel 2. Deskriptif Data DM Siswa Pada Kelas yang mengikuti model pembelajarang langsung

\begin{tabular}{cccc}
\hline Kelas Interval & Kategori & Frek & $\mathbf{( \% )}$ \\
\hline $\mathrm{X} \geq 118.05$ & Tinggi $(\mathrm{T})$ & 5 & 20.83 \\
$103.64 \leq \mathrm{X}<118.05$ & Sedang $(\mathrm{S})$ & 14 & 58.33 \\
$\mathrm{X}<103.64$ & Rendah $(\mathrm{R})$ & 5 & 20.83 \\
Jumlah & & 24 & 100 \\
\hline
\end{tabular}

Data hasil tes KMM dikumpulkan dan dianalisis untuk mengetahui KMM siswa sebelum dan sesudah perlakuan berupa model pembelajaran TTW pada kelas eksperimen dan pembelajaran langsung pada kelas kontrol. Data ini diperoleh dari hasil pretest, posttest dan $N$ Gain KMM siswa.

Rangkuman hasil analisis deskriptif data $N$-Gain KMM siswa yang diberi model pembelajaran TTW disajikan pada Tabel 3.

Tabel 3. Deskriptif Data $N$-Gain KMM Kelas yang diberi model pembelajaran TTW

\begin{tabular}{llc}
\hline $\mathbf{N}$ & $\begin{array}{l}\text { Valid } \\
\text { Missing }\end{array}$ & $\mathbf{2 4}$ \\
\hline Rata-rata & & 0,34 \\
Median & & 0,37 \\
Modus & & 0,36 \\
Std. Deviasi & 0,23 \\
Varians & 0,05 \\
Terendah & & 0,22 \\
Tertinggi & 0,73 \\
\hline
\end{tabular}

Tabel 4. Kategori $N$-Gain KMM Kelas yang diberi model pembelajaran TTW

\begin{tabular}{ccc}
\hline Kategori Ngain & Frek & $\mathbf{( \% )}$ \\
\hline Tinggi (T) & 2 & 8,33 \\
Sedang (S) & 15 & 62,50 \\
Rendah (R) & 7 & 26,17 \\
Jumlah & 24 & 100 \\
\hline
\end{tabular}


Rangkuman hasil analisis deskriptif data $N$-Gain $\mathrm{KMM}$ siswa yang diberi pembelajaran langsung disajikan pada Tabel 5.

Tabel 5. Deskriptif Data N-Gain KMM Kelas yang diberi pembelajaran langsung

\begin{tabular}{lcc}
\hline \multicolumn{1}{c}{$\mathbf{N}$} & $\begin{array}{c}\text { Valid } \\
\text { Missing }\end{array}$ & $\mathbf{2 4}$ \\
& & 0,25 \\
\hline Rata-rata & & 0,33 \\
Median & & 0,36 \\
Modus & & 0,17 \\
Std. Deviasi & & 0,03 \\
Varians & & 0,65 \\
Interval & & 0,20 \\
Terendah & & 0,45 \\
Tertinggi & & \\
\hline
\end{tabular}

Tabel 6. Kategori $N$-Gain KMM Kelas yang diberi pembelajaran langsung

\begin{tabular}{ccc}
\hline Kategori Ngain & Frek & $(\boldsymbol{\%})$ \\
\hline Tinggi $(\mathrm{T})$ & 0 & 0.00 \\
Sedang $(\mathrm{S})$ & 14 & 58,33 \\
Rendah $(\mathrm{R})$ & 10 & 41,67 \\
Jumlah & 24 & 100 \\
\hline
\end{tabular}

Hasil analisis deskriptif terhadap disposisi matematika siswa disajikan pada nilai KMM siswa dari kedua kelas Tabel 7 berdasarkan pengelompokan kategori

Tabel 7. Deskripsi Nilai KMM Siswa berdasarkan Kategori Disposisi Matematik

\begin{tabular}{cccccccc}
\hline \multirow{2}{*}{ Kategori } & & \multicolumn{6}{c}{ Pembelajaran Menggunakan } \\
DM & Stats & \multicolumn{3}{c}{ Kelas Eksperimen } & \multicolumn{3}{c}{ Kelas Kontrol } \\
& & Pre & Post & N-Gain & Pre & Post & N-Gain \\
\hline \multirow{2}{*}{ DM } & n & 9 & 9 & 9 & 5 & 5 & 5 \\
Tinggi & Rataan & 22,05 & 45,33 & 0,29 & 17,60 & 32,80 & 0,18 \\
& St. Dev & 10,73 & 17,66 & 0,07 & 13,45 & 22,16 & 0,16 \\
DM & n & 7 & 7 & 7 & 14 & 14 & 14 \\
Sedang & Rataan & 21,71 & 44,00 & 0,28 & 17,14 & 26,00 & 0,11 \\
& St. Dev & 8.59 & 14,04 & 0,11 & 9,33 & 16,21 & 0,07 \\
DM & n & 8 & 8 & 8 & 5 & 5 & 5 \\
Rendah & Rataan & 23,00 & 40,00 & 0,22 & 21,10 & 26,80 & 0,07 \\
& St. Dev & 11,06 & 13,35 & 0,02 & 9,21 & 11,10 & 0,02 \\
\hline
\end{tabular}

Perbandingan Rataan N-Gain

KMM sesuai Kategori DM lebih jelasnya juga dapat dilihat pada gambar 1 berikut 


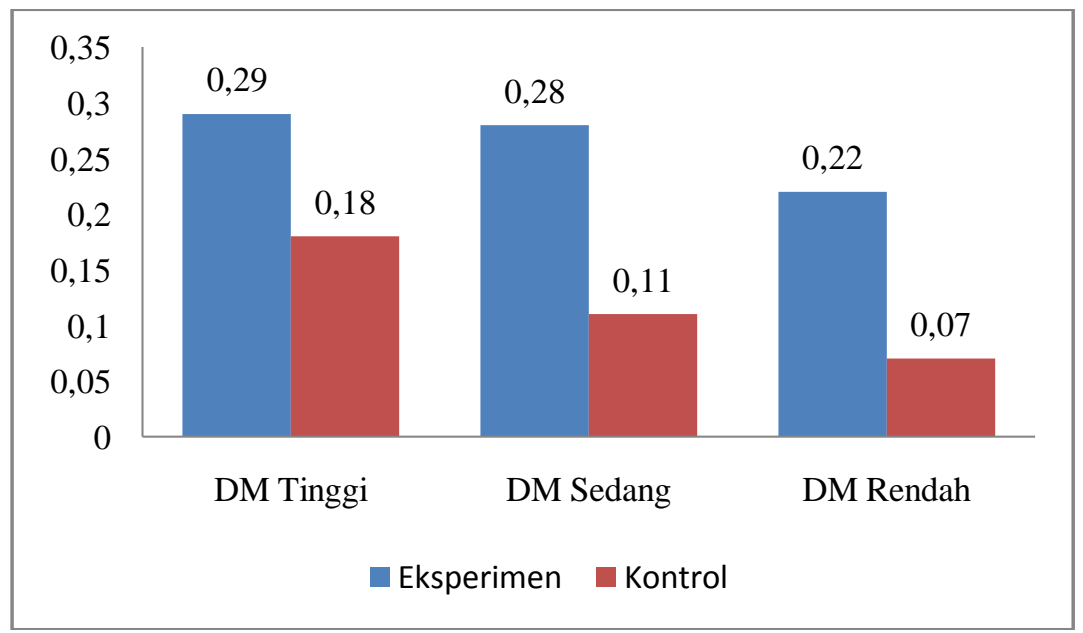

\section{Gambar 1. Perbandingan Rataan N-Gain KMM sesuai Kategori DM}

Berdasarkan interpretasi nilai $N$ Gain, rata-rata peningkatan KMM siswa pada kelompok DM tinggi yang mengikuti model pembelajaran TTW termasuk dalam kategori sedang sedangkan yang mengikuti pembelajaran langsung termasuk dalam kategori rendah. Rata-rata peningkatan KMM baik siswa pada kelompok DM sedang maupun DM rendah yang mengikuti model pembelajaran TTW dan yang mengikuti pembelajaran langsung termasuk dalam kategori rendah.

Hipotesis 1 sampai dengan 6 diuji menggunakan uji $t$ beda dua rata-rata. Berdasarkan hasil analisis uji hipotesis 1 diperoleh bahwa nilai $\mathrm{t}=10,222$ dengan Sig. $=0,000$. Karena nilai Sig. $/ 2<\alpha=$ 0,05 , maka $\mathrm{H}_{0}$ ditolak. Dengan ditolaknya $\mathrm{H}_{0}$ maka dapat disimpulkan bahwa secara signifikan terdapat peningkatan KMM siswa yang dajar dengan model pembelajaran TTW.

Berdasarkan hasil analisis uji hipotesis 2 diperoleh bahwa nilai $\mathrm{t}=8,085$ dengan $\quad$ Sig. $=0,000$. Karena nilai Sig. $/ 2<\alpha=0,05$, maka $\mathrm{H}_{0}$ ditolak. Dengan ditolaknyanya $\mathrm{H}_{0}$ maka dapat disimpulkan bahwa secara signifikan terdapat peningkatan KMM siswa yang dajar dengan model pembelajaran Langsung.

Berdasarkan hasil analisis uji hipotesis 3 diperoleh bahwa nilai $\mathrm{t}=2,375$ dengan Sig. $=0,022$. Karena nilai Sig. $/ 2<$ $\alpha=0,05$, maka $\mathrm{H}_{0}$ ditolak. Dengan ditolaknyanya $\mathrm{H}_{0}$ maka dapat disimpulkan bahwa secara signifikan peningkatan KMM siswa yang mengikuti model pembelajaran TTW lebih tinggi daripada KMM siswa yang mengikuti pembelajaran langsung.

Hipotesis 4

Berdasarkan hasil analisis uji hipotesis 4 diperoleh bahwa nilai $\mathrm{t}=2,636$ dengan $\quad$ Sig. $=0,022$. Karena nilai Sig. $/ 2<\alpha=0,05$, maka $\mathrm{H}_{0}$ ditolak. Dengan ditolaknyanya $\mathrm{H}_{0}$ maka dapat disimpulkan bahwa secara signifikan peningkatan KMM siswa yang mengikuti model pembelajaran TTW lebih tinggi daripada KMM siswa yang mengikuti pembelajaran langsung pada siswa dengan DM tinggi.

Berdasarkan hasil analisis uji hipotesis 6 diperoleh bahwa nilai $\mathrm{t}=2,240$ dengan Sig. $=0,037$. Karena nilai Sig. $/ 2<$ $\alpha=0,05$, maka $\mathrm{H}_{0}$ ditolak. Dengan ditolaknyanya $\mathrm{H}_{0}$ maka dapat disimpulkan bahwa secara signifikan peningkatan KMM siswa yang mengikuti model pembelajaran TTW lebih tinggi daripada KMM siswa yang mengikuti model pembelajaran langsung pada siswa dengan DM sedang.

Berdasarkan hasil analisis uji hipoetsis 7 diperoleh bahwa nilai $\mathrm{t}=$ 
2,780 dengan Sig. $=0,018$. Karena nilai Sig. $/ 2<\alpha=0,05$, maka $\mathrm{H}_{0}$ ditolak. Dengan ditolaknyanya $\mathrm{H}_{0}$ maka dapat disimpulkan bahwa secara signifikan peningkatan KMM siswa yang mengikuti

\section{PEMBAHASAN}

Hasil analisis data baik dari analisis deskriptif maupun analisis inferensial menunjukan bahwa ada perbedaan KMM siswa pada masing-masing kelas yang mendapat model pembelajaran TTW dan model pembelajaran langsung. Tetapi setelah membandingkan pada masingmasing kelas melalui uji statistik dan deskriptif, maka terdapat perbedaan yang signifikan KMM siswa antara kelompok siswa yang pembelajarannya menggunakan model pembelajaran TTW dengan kelompok siswa yang pembelajarannya menggunakan model pembelajaran langsung. Hal ini terlihat pada nilai rata-rata $N$-Gain kedua kelompok yang menyimpulkan bahwa nilai rata-rata $N$-Gain KMM siswa yang pembelajarannya menggunakan model pembelajaran TTW lebih tinggi dari pada nilai rata-rata $N$-Gain kelompok siswa yang pembelajarannya menggunakan model pembelajaran langsung.

Dari hasil uji hipotesis yang telah dikemukakan sebelumnya ditemukan bahwa terdapat perbedaan KMM siswa yang mengikuti model pembelajaran TTW dan siswa yang mengikuti model pembelajaran langsung. Artinya, perbedaan KMM itu ada karena perbedaan perlakuan pembelajaran yang diberikan pada masing-masing kelas. Dalam hal ini dapat dikatakan bahwa model pembelajaran TTW lebih baik dalam hal meningkatkan KMM siswa dibandingkan dengan model pembelajaran langsung khususnya pada materi Kubus dan Balok. Berikut ini akan dibahas secara umum model pembelajaran terhadap KMM siswa ditinjau dari disposisi matematika.

Berdasarkan hasil penelitian pada menunjukkan perbedaan KMM model pembelajaran TTW lebih tinggi daripada KMM siswa yang mengikuti pembelajaran langsung pada siswa dengan DM rendah.

berdasarkan model pembelajaran ditinjau dari disposisi matematik siswa. Pada kelompok siswa dengan kategori DM tinggi yang mendapat model pembelajaran TTW memperoleh rataan $N$-Gain KMM sebesar 0.41 lebih besar dibandingkan dengan rataan KMM siswa yang mendapat model pembelajaran langsung yaitu sebesar 0.20. Pada kelompok siswa dengan DM sedang yang mendapat model pembelajaran TTW memperoleh rataan $N$ Gain KMM sebesar 0.291 lebih besar dibandingkan dengan rataan $N$-Gain KMM siswa yang mendapat model pembelajaran langsung yaitu sebesar 0.111. Pada kelompok siswa dengan DM rendah yang mendapat model pembelajaran TTW memperoleh rataan $N$ Gain KMM sebesar 0.23 lebih besar dibandingkan dengan rataan $N$-Gain KMM siswa yang mendapat model pembelajaran langsung yaitu sebesar 0.02. Berdasarkan uraian tersebut di atas, dapat disimpulkan bahwa terdapat pengaruh model pembelajaran TTW terhadap KMM siswa ditinjau dari disposisi matematika.

Hasil penelitian juga menyimpulkan bahwa secara umum terdapat perbedaan yang signifikan peningkatan KMM siswa antara kelas yang mengikuti model pembelajaran TTW dan kelas yang mengikuti model pembelajaran langsung ditinjau dari disposisi mtematika.

Hasil penelitian ini sejalan dengan hasil-hasil penelitian terdahulu bahwa siswa yang mendapat model pembelajaran TTW secara signifikan memperoleh KMM siswa yang lebih tinggi dibandingkan dengan siswa yang mendapat pembelajaran konvensional ataupun pembelajaran langsung. 
Faktor model pembelajaran yang digunakan guru berpengaruh signifikan terhadap KMM siswa ditinjau dari disposisi matematik serta aktivitas siswa selama mengikuti proses pembelajaran. Pada model pembelajaran langsung, guru merupakan sentral dari kegiatan proses pembelajaran dan membuat siswa berperan pasif. Akibatnya siswa menjadi kurang Aktif terhadap prosese pembelajaran, tidak menumbuh kembangkan rasa keingin tahu siswa terhadap materi yang dipelajari, siswa merasa bosan dan berharap proses pembelajaran segera berakhir sehingga kurang mampu dalam mengembangkan KMM siswa. Hal ini dapat di lihat dari hasil penelitian yang telah di paparkan sebelumnya bahwa KMM siswa yang mendapat model pembelajaran langsung lebih rendah daripada siswa yang mendapat model pembelajaran TTW. Dalam proses pembelajaran dengan menggunakan model pembelajaran langsung terhadap KMM siswa tidaklah mudah dilakukan. Oleh karena itu, dibutuhkan suatu model pembelajaran TTW yang memudahkan siswa melakukan suatu proses KMM, siswa merupakan sentral dalam proses pembelajaran, memfasilitasi siswa untuk melakukan penemuan sehingga siswa tertarik dalam mengikuti proses pembelajaran.

Jika dilihat dari karakteristik model pembelajaran TTW, sebagaimana telah dijelaskan sebelumnya kondisi ini dimungkinkan terjadi. Siswa yang mendapat model pembelajaran TTW belajar secara kelompok melalui proses penyelidikan permasalahan (think). Pada

\section{KESIMPULAN DAN SARAN}

Kesimpulan dari penelitian ini sebagai berikut:

1. Proses pembelajaran TTW pada siswa kelas VIII SMP Negeri 25 Konawe Selatan terlaksana dengan baik. Secara kelompok siswa terlibat dalam menyelesaikan masalah yang diberikan proses penyelidikan masalah tersebut, siswa menggunakan segala potensi yang dimilikinya untuk memecahkan masalah yang diberikan baik secara mandiri maupun secara kelompok untuk diajukan pada diskusi kelas (talk). Ketika siswa mendapat masalah dalam proses pemecahan, mereka mengemukakan pertanyaan kepada guru atau kepada siswa lain untuk memperjelas masalah yang diberikan. Pada saat yang sama, siswa dapat saling berbagi, mempertahankan, atau menghargai pendapat atau ide-ide pemecahan masalah yang dikemukakan oleh siswa lain. Kegiatan ini dapat mengembangkan proses berpikir pemahaman siswa terhadap masalah matematika yang diberikan sehingga dapat mempermudah siswa menemukan apa yang dicari untuk memecahkan masalah tersebut. Pada proses akhir dari bagian ini (write), siswa menuliskan hasil pekerjaannnya secara jelas untuk melihat tahap-tahap penyelesaian suatu permasalahan dengan mengguakan operasi yang benar dan juga hasil yang benar.

Secara umum, dapat disimpulkan bahwa terdapat perbedaan model pembelajaran TTW dan model pembelajaran langsung terhadap KMM siswa secara keseluruhan maupun berdasarkan kategori disposisi matematik. Hal ini mengindikasikan bahwa ternyata ada pengaruh model pembelajaran terhadap KMM siswa. Berdasarkan hasil penelitian dan pembahasan, model pembelajaran TTW berpengaruh lebih baik daripada model pembelajaran langsung terhadap KMM siswa.

dan guru membimbing seperlunya saja.

2. Disposisi mtematik siswa pada kelas VIII SMP Negeri 25 Konawe Selatan terdiri dari tiga kategori yaitu Disposisi Matematika tinggi, sedang dan rendah. 
3. Ada pengaruh model pembelajaran TTW terhadap peningkatan Kemampuan Menulis Matematik siswa ditinjau dari disposisi matematik siswa terhadap matematika. Secara signifikan peningkatan KMM siswa yang mengikuti model pembelajaran TTW lebih tinggi daripada siswa yang mengikuti model pembelajaran langsung ditinjau dari disposisi matematika.

4. Secara signifikan peningkatan KMM siswa yang mengikuti model pembelajaran TTW lebih tinggi daripada siswa yang mengikuti model pembelajaran langsung.

5. Secara signifikan KMM siswa yang mengikuti model pembelajaran TTW lebih tinggi daripada KMM siswa yang mengikuti model pembelajaran langsung baik ditinjau dari siswa yang memiliki DM tinggi, sedang maupun rendah.

\section{DAFTAR PUSTAKA}

Ambarjaya S, Beni. 2012. Psikologi Pendidikan dan pengajaran: teori dan praktik. Yogyakarta: CAPS.

Arikunto. 2002. Prosedur Penelitian . Jakarta: Rineka Cipta.

Aryani, K. 2010. Peningkatan Kemampuan Menulis dan Pemahaman Konsep Matematika Melalui Pembelajaran Dengan Strategi Writing From A Prompt dan Writing in Performance Task Pada Siswa SMP. Tesis UPI: Bandung.

Barli Bram. 2002. Membangun Pemahaman Siswa melalui Model Pembelajaran Think Talk Write pada Materi Fungsi Invers Di Kelas II SMAN Baktiya. Tesis tidak diterbitkan. Malang: PPS Universitas Negeri Malang.

Depdiknas. 2008. Kurikulum Tingkat Satuan Pendidikan. Jakarta : Dikmenum. Depdiknas.
Saran yang dapat diberikan pada penelitian ini yaitu:

1. KMM siswa perlu dikembangkan untuk membantu siswa dalam menyelesaikan masalah, baik dalam pembelajaran matematika maupun dalam kehidupannya sehari-hari. Salah satu alternatif pembelajaran yang dapat digunakan adalah menerapkan model pembelajaran TTW.

2. Guru perlu mengembangkan lembar kerja siswa (LKS) yang dapat diaplikasikan dan digunakan pada materi matematika dengan menerapkan model pembelajaran TTW.

3. Guru perlu memberikan soal-soal non rutin yang berisikan aspek-aspek KMM dalam pembelajaran di kelas agar kemampuan siswa terlatih dalam menyelesaikan masalah matematika.

Halmaheri. 2004. Mengembangkan Kemampuan Komunikasi Matematika Melalui Strategi ThinkTalk-Write (TTW) dalam Kelompok Kecil (Studi Eksperimen di SMPN 3 Kuantan Kabupaten Kuantan Singingi Propinsi Riau). Tesis pada FMIPA UPI Bandung.

Huinker \& Laughin. 1996. Think-TalkWrite (TTW). [Online]. Tersedia: www.mtsd.k12.wi.us. [25 September 2007].

Kilpatrick, J.,Swafford, J.,\& Findel, B. 2001. "Adding It $U p$ : Helping Children Learn Mathematics". Washington, DC : National Academy - Press.

Kesumawati. 2010. Peningkatan Kemampuan Pemahaman, Pemecahan Masalah, dan Disposisi Matematis Siswa Melalui Pendidikan Matematika Realistik. Disertasi-UPI: Bandung. 
Mahmudi, Ali. 2009. Komunikasi dalam Pembelajaran Matematika. Makalah Termuat pada Jurnal Pendidikan UNHALU Vol. 8, No.1, Februari 2009.

Reni Untarti. 2010. Keefektifan Strategi Pembelajaran Think- Talk-Write (TTW) Pada Pembelajaran Statistika dan Peluang Ditinjau Dari Kompetensi dan Komunikasi Matematika Siswa SMP N 1 Ngaglik. Skripsi Universitas Negeri Yogyakarta: Tidak diterbitkan.

Slamet 2008. Pengertian Dasar Problem Solving".[Online]. Tersedia: http:// p4tkmatematika.org/.../problemsolvi ng/PengertianDasarProblem Solving _ smd.pdf [29 Desember 2010].

Soewarno Handayaningrat. 1990. "Pengajaran Matematika Untuk Sekolah Menengah". Jakarta : Departemen Pendidikan dan Kebudayaan.

Sugiyono. 2008. Metode Penelitian Kuantitatif Kualitatif dan $R \& D$. Bandung : ALFABETA.

Suherman, dkk. 1990. Common texbook. Strategi Pembelajaran Matematika Kontemporer. JICA-UPI Bandung.

Sumarmo, U. 2010. Berfikir dan Disposisi Matematik: Apa, Mengapa, dan Bagaimana Dikembangkan pada Peserta Didik. Bandung: FPMIPA UPI.

Twisli Happy Rosdian. 2010. "Penerapan Pembelajaran Kooperatif Model Think- Talk-Write (TTW) Pokok Bahasan Persamaan Linier Satu Variabel (PLSV) Pada Siswa Kelas VII G Semester Gasal SMP Negeri 1 Suboh-Situbondo Tahun Pelajaran 2009/2010". [Online]. Tersedia: http:// digilib.unej.ac.id , ... , $\underline{\text { Pendidikan_Matematika }}>\underline{2010}$ ). [1 Januari 2015]
Yuanari, Novita. 2011. "Penerapan Strategi TTW (Think-Talk-Write) sebagai Upaya Meningkatkan Kemampuan Pemecahan Masalah dan Disposisi Matematis Siswa Kelas VIII SMP N 5 Wates Kulonprogo. Skripsi S-1 Progdi Pendidikan Matematika. Yogyakarta: FMIPA Universitas Negeri Yogyakarta.

Yunarti. 2003. Model Kooperatif Tipe Think Tallk Write (TTW) untuk Meningkatkan Kemampuan Menulis Karangan Deskripsi dan Berpikir Kritis. [Online]. Tersedia: http://jurnal.upi.edu/file/15-

Zulkarnaini-EDIT.pdf $\quad[17$ Januari 2013]

Yunarti, Tina. 2011. Pengaruh Metode Socrates terhadap Kemampuan dan Disposisi Berpikir Kritis Matematis Siswa SMA. Disertasi, Bandung: UPI 